INFO- 2258

UDK: 34:32:341.231.14

Primljeno / Received: 2021-10-11

Preliminary Communication

https://doi.org/10.32914/i.55.1-2.12

\title{
PUBLIC INTEREST AND GOOD GOVERNANCE IN THE RULE OF LAW ASPECT
}

\author{
Anastasiia I. Berendieieva, Alla H. Pyshna², Iuliia S. Bakhtina², Andrii M. \\ Kuchuk ${ }^{4}$
}

Department of Administrative Activities of the Police, Faculty of Training Specialists for Preventive Activities, Odessa State University of Internal Affairs, Odessa, Ukraine"; Department of Administrative Activities of the Police, Faculty of Training Specialists for Preventive Activities, Odessa State University of Internal Affairs, Odessa, Ukraine²; Department of Legal Disciplines, Interregional Academy of Personnel Management, Odessa, Ukraine; ; Department of Law and Methodology of Teaching Jurisprudence, Sumy State Pedagogical University named after A.S. Makarenko, Sumy, Ukraine ${ }^{4}$

\section{Abstract}

The purpose of the article is to elucidate the relationship between good governance, the public interest and the rule of law, given the declining tendency of the rule of law indices around the world and in the crisis conditions. The study is based on a systematic method that has allowed to establish the relationship between the rule of law, good governance and the public interest and determines the use of content analysis and hermeneutic methods. The article clarifies that the rule of law and human rights are the values of a democratic society that determine the content and direction of public authorities' and legislation activities, argues that the declining tendency of the rule of law index does not indicate a devaluation of the rule of law and citizens' disbelief in its effectiveness; instead, this tendency might indicate a certain change in the vector of public authorities activity, and improper exercise of powers by established means. A comparative analysis of the two countries and their governance systems between Ukraine and Germany showed differences in countries with different rule of law indices. Good governance and the rule of law are interdependent and cannot exist without each other. The main provisions of the article can be guidelines for improving public administration within states implementing the rule of law.

Keywords: democracy; good governance; human rights; public interest; rule of law.

\section{INTRODUCTION}

Given that government has existed for 7,000 years, it has become a great value for many countries and cultures. The rule of law is a value of Western law culture as well. The urgency to recognize the rule of law is indicated as a condition for accession to a number of international treaties. Thus, the preamble to the Convention for the Protection of Human Rights and Fundamental Freedoms /1/ states about "a common heritage of political traditions, ideals, freedom and the rule of law". The rule of law is usually considered jointly with the following values as human rights, human dignity, and democracy, which provides for the public interest provision and good governance within society. Public authorities also recognize the importance of understanding the interrelationship between these phenomena. Thus, the UK Government notes that sustainable development, democracy, good governance and human rights are factors in advancing an international system based on the rule of law /2/. 
This issue is constantly in the spotlight of scientists. The relationship between good governance and human rights has been the subject of a study by a team of authors led by Pradeep Kumar /3/, certain aspects of public administration in the context of these values were studied by A. Aparov, O. Ivanii, R. Shestopalov, L. Adashys, O. Morozov $/ 4 /$, political aspects of good governance in relation to human rights, and the rule of law were explored by Dzhamal Z. Mutagirov /5/. Good governance and democracy, their relationship to the rule of law and human rights were described by Wei Zhang /6/, as well as B.M. Sharma \& Abhishek. Sharma /7/, Poonam Lamba /8/. The regional aspect of this topic was the subject of a study by Yubaraj Sangroula /9/.

At the same time, according to The World Justice Project Rule of Law Index® /10/, the rule of law rate in many states has been declining over the past three years, indicating a downward trend. Moreover, the decline in the rule of law rate has been noted in various states around the world. This determines the necessity to rethink the relationship between good governance, the public interest and the rule of law in contemporary conditions. The issue of the correlation between good governance, public interest and the rule of law has become relevant in the context of the COVIDCrisis. Professor K. Lachmayer /11/ emphasized certain aspects of the government's restriction of the rule of law. Therefore, this article attempts to rethink the established views on the relationship between good governance, public interest and the rule of law in modern conditions, given the declining of the rule of law rate around the world, as well as in crisis conditions.

Herewith, we will analyze general provisions (trends) on the subject of research within European states and focus on two states: the Federal Republic of Germany and Ukraine. These states are selected based on the following: first, each of them has long been among the 10 countries with a high index of the rule of law and democracy (Germany) or with a low level (Ukraine). The figures for appeals to the European Court of Human Rights are similar:
Ukraine is in the top three in terms of the number of complaints against it (which is additional evidence of the above data on the rule of law and democracy), the number of appeals to the European Court of Human Rights against Germany. is low. Herewith, these states are parties to the Convention for the Protection of Human Rights and Fundamental Freedoms and territorially belong to Europe. Ukraine was proclaimed law-abding state in the Constitution /12/ (the rule of law theory was formed in Germany). The legal systems of both Ukraine and the Federal Republic of Germany belong to the system of continental law. In addition, it is the Federal Republic of Germany Constitutional Court's /13/ /14/ activities that are largely associated with the formation and dissemination of legal ideas that influence the formation of modern human rights theory (and, consequently, of the rule of law). Thus, let us mention the decision of 2006 as to recognition unconstitutional the law on aviation security, which provided for the possibility of destroying a plane hijacked by terrorists (this decision formulates a rather progressive interpretation of human dignity). As well as the decision of 2021 on the unconstitutionality of the Federal Law on Climate Protection provisions because of their incompatibility with human rights, the provisions do not specify clear provisions for further emission reductions (this decision is associated with "future Constitution's action " and positive obligations of the state on the future generations' protection).

The abovementioned allows us to conclude about a certain commonality of elected states and, at the same time, sharp differences in ensuring human rights, democracy and the rule of law level (which, according to the study, is related to good governance and public interests implementation. The level of citizens' interest in politics can indicate the following: in Germany - 78.5\% of respondents are interested in politics, in Ukraine - $34.69 \%$ - according to 2020 ) /15/.

The basis of this study is a systematic method allowing establish the relationship between the rule 
of law, good governance and the public interest. Using the method of content analysis particular decisions of the European Court of Human Rights on the importance of the rule of law, understanding of good governance and determining the proportionality of restrictions on human rights in order to ensure the public interest were processed. The analysis of the decisions of the European Court of Human Rights was carried out using the hermeneutic method.

The starting point of our study is a methodological conclusion about the possibility of free development of an individual only in democracy conditions, when human rights are the basis of public authority - a person interaction, and the social order proceeds from the recognition of the human dignity value. It is within such a society that good governance, the public interest and the rule of law can function properly. Authoritarian and totalitarian regimes do not recognize human rights (more precisely, deny the natural and inalienable nature of human rights), as the values are recognized the interests of the ruling elite and the interests of the public service (and to this day in some post-soviet states such a criminal offense as abuse of power is related to such a feature as the activities of a civil servant against the interests of the service) for which the euphemism "common good" is used. At the same time, it is taken into account that within democratic regime human rights are not always properly ensured; the connection between democracy and human rights is not entirely conditioned. The study uses the results of the annual Rule of Law Index and the Democracy Index, allowing reveal development trends in the relevant phenomena - of the rule of law, democracy and related human rights.

\section{THE RELEVANCE OF THE RULE OF LAW INDEX}

The rule of law and human rights are the values of a democratic society, determining the content and direction of public authorities' activities and legislation. The downward trend in the rule of law index does not indicate a devaluation of the rule of law and citizens' distrust of its effectiveness; instead, this trend might indicate a certain change in the vector of public authorities' activities, and improper exercise of powers by the established means. Characterization of the system as democratic does not mean full provision of human rights within such a society and the absence of their violations. However, it is in a democratic society that the rule of law and good governance might function. Good governance and the rule of law are interdependent and cannot exist without each other. The fundamental task of good governance is to ensure human rights that might be contrary to the public interest. It is the public interest that can be the legitimate aim of restricting human rights. However, such a restriction cannot be disproportionate and encroach on the essential content of human rights, imposing an excessive burden on the individual. Thus, in resolving the conflict between human rights and the public interest, good governance should be based on the rule of law.

Since the second half of the twentieth century, there has been a tendency in the world to spread human rights, democracy, and the rule of law. There is a well-established view of the impossibility of human rights existence within non-democratic societies. At the same time, today, as Carolien van Ham and Louise Chappell /16/ (point out, "it seems increasingly clear that democracy and human rights do not necessarily go together. Human rights violations are often justified in name of democracy and freedom, and even in established democracies human rights violations are common. Todd Landman /17/ came to a similar conclusion. In this context, the study of A. Horn $/ \mathbf{1 8} /$, the subject of which is The Human Right to Democracy, is also quite timely.

It is difficult to disagree with the conclusions of the abovementioned authors. At the same time, it is worth noting, indeed, democracy does not necessarily lead to human rights provision. It is hardly possible that human rights will not be violated in a democratic society (or in any other). However, it is in democratic societies that human rights are possible. Authoritarian and totalitarian systems by their nature do not provide for the recognition of the natural character of human 
rights, do not recognize them as a means of limiting their own power, on the contrary: human rights are perceived only as opportunities provided by the state and implemented within the framework fixed by public authorities; if human rights conflict with the interests of the state, the priority is given to the interests of the state.

Indicative in this context might be the comparison of the rule of law index, which we mentioned above, with the Democracy Index, determined by The Economist Intelligence Unit /19/, to which it is possible to impose statistics of appeals to the European Court of Human Rights /20/. The results of comparing these data confirm our thesis about the relationship of the studied phenomena. The subject of the study involves the coverage of three components: the public interest, good governance and the rule of law.

In this context, it is worth noting the research by Stephen M. King, Bradley S. Chilton, Gary E. Roberts $/ \mathbf{2 1} /$, in which the authors note the focus of scholars and public authorities on the public interest understanding. The authors concluded that a number of normative and pragmatic elements are in the public interest, emphasizing the necessity to limit power to constitutional principles, the government's compliance with democratic values, "the practice of nonidiosyncratic and universalized ethical administrative leadership and decision making".

In general, there is a consensus on the understanding of the public authority's task in serving people and the focus of public policy on public interests' implementation /22/ and on the secondary nature of public interest content in comparison with the issue on subjects and means of public interests' determining /23/.

Given the abovementioned research methodology, we will describe the understanding of the concept of "public interest" in the Federal Republic of Germany. Exploring the public interest, Robert Werpmann /24/ systematically analyzes German law, interpreting the meaning of the concept of "public interest". According to the researcher, the legal database "Federal Law" on CD-ROM contains 427 regulations implicating the term "public interest", and the content of these terms is quite different.

According to Regina Viotto /25/, the issue of what constitutes a public interest is less relevant (given that the content of the public interest may vary depending on the state of society development) than the issue of who and by what method determines the content of the public interest. The basis for answering this question is the Constitution of the Federal Republic of Germany /26/, Art. 20 of which states that the people is the source of the state power. Power is exercised by the people through elections and voting, as well as through special legislative, executive and judicial bodies. Accordingly, it is the people who determine the public interest. However, it is hardly possible for all citizens to hold the same opinion, which is why there should be some minimum level at which the sum of private interests acquires the quality of public interest, despite the presence of opposing interests of individuals. In addition, it should be borne in mind that the public interest is not simply a set of private interests.

The indication of R. Viotto /27/ that the public interest cannot be reduced to the principle of unanimity is crucial for understanding the public interest. Democracy requires decisions based on the principles of democratic equality and justice. The principle of unanimity may block a decision due to the possibility of a veto. After all, more people can act according to their own will by making the right decision.

It should be noted that the issue of public interest became relevant in the context of counteracting the COVID-19 pandemic, when there was a significant restriction of human rights, which was justified by the necessity to preserve the health of the population. Some aspects of this issue have been studied by Barbara Schuster, Linda Tizek, Maximilian C Schielein, Stefanie Ziehfreund, Kathrin Rothe, Christoph D Spinner, Tilo Biedermann, Alexander Zink /28/, Pierpaolo Gori, 
Aniel Pahladsingh /29/, Sanja Jovičić /30/, H. v. Kolfschooten and A. de Ruijter /31/.

Regarding the understanding of the concept of "public interest" in Ukraine, it is worth noting the following.

Note that the term "public interest" is mostly not used in the post-soviet states, but the terms "society interests", "common good" and others were widely used. At the same time, the use of this term is more typical of administrative and financial law $/ 32 /, / 33 /, / 34 /$.

It should be noted that M. Karmalita /35/ connects the state as a subject of expression of public interest: "The state has a public interest in taxation this is to receive fully planned tax revenues", and A. Chub /36/ uses a specific term "Legal public rights of an individual", which, in our opinion, is an attempt to bring the soviet jurisprudence legacy closer to the values of Western legal culture. Only some Ukrainian scholars study the public interest in the aspect of constitutional law /37/, /38/.

It is worth agreeing with L. Zolotukhina /39/ that the preservation of the confrontation of "state", "public" and "private" interests in close connection with the regulatory uncertainty of the category "public interest" has its negative effect of lack of effective mechanisms for its implementation and protection, making it impossible to exercise the function of public participation in managerial decisions making and control over their implementation. Although the theory of public interest is not new to European doctrine, it is successfully implemented at the appropriate level of legal effectiveness within the European Union states, in particular the Federal Republic of Germany, the Republic of Poland, the French Republic (Zolotukhina, 2019).

In this context, it should be noted that in 2016, by amending the Constitution of Ukraine /40/, the term "state prosecution" was changed to "public prosecution". The Grand Chamber of the Supreme Court /41/ in the decision of 13 February
2019 in case No. 233/4308/17 on the claim of the State Aviation Service to the limited liability company "Budghenkontrakt" indicates that beyond the general definition of "public interest" there are crucial for a significant number of physical and legal entities needs, which in accordance with the legally established competence are provided by the subjects of public administration. That is, the public interest is nothing more than a certain set of private interests.

In general, we can agree with this understanding of public interest, but at the same time, a number of questions arise. First, it is a quantitative aspect of the public interest: how many private interests form public interest? Is there always a certain amount of private interest form the public one? Under what conditions does this happen or when it might not happen? If we consider that a certain majority reflects the public interest, then such a majority should be uncertain (anyone can make it, it is not a closed group). In this case, changes in the composition of such a "group" will not affect the change of interest, which indicates the difference between private interests and public interest. Thus, various business associations, having a predominantly private purpose, cannot reflect the public interest $/ \mathbf{4 2} /$.

Second, is it always that private interests of the majority of the population form the public interest? In this context, it should be noted that the legislation of a large number of states prohibits a referendum on taxes, amnesty, and budget. It should be noted that in any case the public interest is not limited to the interest of an individual, and therefore applies to issues that are public in nature and applies not to the individual, but to social entities. In the context of the topic we are studying, the public interest is always related to the sphere of public administration, and therefore concerns power relations. At the same time, ensuring the public interest belongs to the powers of public administration bodies. It is through public authorities that the will of the people is realized, which is why these bodies should ensure the public interest. This determines the requirement for public administration - its democracy, which 
will be a factor in the interests of the majority ensuring.

Based on the abovementioned, we can draw certain conclusions about the content of the public interest. First, the basis for regulating the relationship between a person and public administration is human rights. They determine the limits of public authority activity and provide a person with the opportunity for free development. In the presence of a conflict between human rights and the demands of public authorities, the priority belongs to human rights. That is why the public interest might not but presuppose the obligation of public authorities to recognize and ensure human rights. Second, as follows from the first, public authority should act within the rule of law boundaries, because human rights and the rule of law cannot exist within society separately. If society does not recognize the rule of law, then human rights are not recognized within it (just as if human rights are not perceived as natural and inalienable, the rule of law is not recognized, because under such conditions it can only be within those limits determined by the state, but it is no longer the rule of law, but the rule of absolute public power). Third, the logical conclusion from the previous paragraphs is the public interest in fair, honest, equal, and non-corrupt governance. In our opinion, these provisions reflect the essence of the public interest. At the same time, they point to the connection between the public interest and good governance and the rule of law.

As we can see, there are some differences in the perception of the public interest in the Federal Republic of Germany and Ukraine, despite their belonging to the same legal system. In Germany, scholars focus mainly on finding out the subjects and means of the public interest forming, while in Ukraine it is a problem of the public interest understanding. The level of democracy and the experience of implementing the rule of law is one among the factors of this.
III. THE CHARACTERISTIC OF GOOD GOVERNANCE

With regard to good governance, the situation with the interpretation of the meaning of this concept is better. Thus, B. Shevchuk $/ \mathbf{4 3} /$ notes that in international practice there are provisions that characterize good governance as follows:

a) Participation (This feature is related to democracy and involves the participation of the population in the exercise of power (as it is known, the power of the people can be exercised directly or through the representative bodies);

b) Rule of law (This feature requires, in particular, fair, equal treatment of people, ensuring human rights);

c) Transparency (This feature provides for freedom of information, human access to information about the activities of public administration bodies);

d) Responsiveness (This feature determines the service to all members of society); e) Consensus orientation (This feature is stipulated by the necessity to reach a consensus on procedural issues and involves a balance of interests);

f) Equity (This feature takes into account human interests);

g) Effectiveness and efficiency (This feature implies the obligation of public administration bodies to use resources efficiently to achieve the best result - to satisfy people's interests);

h) Accountability (This feature implies the presence of public control over the public administration bodies' activities);

i) Strategic vision (This feature implies public understanding of the prospects for good governance).

It should be noted that the concept of "good governance" was also reffered to by the European Court of Human Rights. Thus, in the case of Moskal v. Poland European Court of Human Rights 
/44/, considering the violation of Art. 1 of the First Protocol to the Convention for the Protection of Human Rights and Fundamental Freedoms /45/, which enshrines the right to property, stressed the importance of taking into account the principle of good governance, as it is important for authorities to study issues having crucial importance for a person act in a timely and consistent manner.

The European Court of Human Rights /46/ emphasized: "Moreover, the principle of "good governance" requires that where an issue in the general interest is at stake it is incumbent on the public authorities to act in good time, in an appropriate manner and with utmost consistency". The case before the Court concerned the following issues clarification:

a) whether the restriction of property rights served a legitimate aim - "in the public interest",

b) whether a fair balance was struck between human rights and the general interest of the public, since when "Disproportionate burden" is vested on a person this cannot be interpreted as such that being carried out within the limits of "in the public interest".

The principle of "good governance" is taken into account by the European Court of Human Rights and in the cases of Paplauskienè v. Lithuania /47/, Pyrantienè v. Lithuania /48/, Albergas and Arlauskas v. Lithuania /49/, Rysovskyy v. Ukraine /50/. In the case of Rysovskyy v. Ukraine it is emphasized the obligation of the public authorities to establish procedures that will ensure transparency and clarity of their activities and will minimize the risk of error.

The term "good governance" as well as the term "gute Regierungsführung", "gute Staatsführung", "verantwortungsvolle Regierungsführung" is used in the German scientific literature. Its appearance in German

\footnotetext{
${ }^{1}$ This issue was the subject of research by C. Kessler
} /55/, R. Czada /56/, U. Werther-Pietsch. /57/ and also discourse took place in the 1990s and is associated with the international organizations activities, including the United Nations, the World Bank, and the International Monetary Fund. According to C. Offe $/ 51 /$, the main elements of "good governance" include the following: the rule of law, equality of all people before the law and in rights, the ability of governments to form policy and implement it effectively.

The Ministry of Economic Cooperation and Development of the Federal Republic of Germany /52/ notes that good governance is a factor of development. In turn, in order to achieve the goal of good governance, it is necessary to implement a policy of political participation, human rights, the rule of law, decentralization, and the fight against corruption. "Proper governance cannot be ensured from the outside and against the will of influential political and social forces. To ensure the processes of political reform, constructive and stable relations between the state and society should be established. This requires a strong civil society that shapes its interests and participates in political decision-making processes".

Good governance is the foundation of society's development and requires public authorities to form effective courts, administrations, their openness, and respect for human rights. Otherwise, the foundations of society itself are threatened. Therefore, the promotion of good governance for many years has been the main task of German development policy /53/. Good governance is a determinant criterion for determining states to invest. Such governance is characterized by democratic procedures, the rule of law, transparency, and a market economy /54/. The key aspects of good governance are human rights implementation, the democratic procedures effectiveness, the rule of law recognition, and the of public authorities openness and transparency. Good governance is a factor in developing society's potential ${ }^{1}$.

covers the Federal Ministry of Labour and Social Affairs. /58/. 
In Ukraine, scholars mainly focus on the problem of defining the concept of "good governance" and the relationship between the concept of good governance and other concepts in the field of governance, as well as the implementation of the European experience of good governance ${ }^{2}$. At the same time, some scholars associate good governance, first of all, not with the rule of law, but with the principle of legality. Thus, A. Ezerov and Y. Batan $/ 65 /$ note that the first standard of good governance is legality, which requires local governments and centers of administrative services to act in accordance with the law, these entities should not take spontaneous measures even in the process of their powers exercise. $\mathrm{M}$. Lendel /66/ proposes the following measures as directions for the implementation of good governance, in particular:

1) to amend the Constitution of Ukraine, supplementing it with norms that will promote real decentralization;

2) local authorities should develop regulations on public hearings holding, and citizens' general meetings;

3) accession to the European Strategy for Innovation and Good Governance;

4) to develop cards of administrative services, provisions on administrative services transfer to public benefit public organizations;

5) holding competitions such as "Transparent Community". In our opinion, such a formal perception of good governance does not correspond to the essence of this concept.

Thus, we can conclude that there are differences in the intentions of scientists in the Federal Republic of Germany and Ukraine on the issue of good governance: the former focus on the applied aspects of good governance further improving; the second focus on understanding the very

${ }^{1}$ This issue was the subject of research by M. Lendel /59/, G. Kukhareva /60/, T. Arifkhodzhjaeva /61/, N. concept and the possibility of implementing the provisions of Western legal culture on proper governance into Ukrainian realities. This confirms the link between the level of human rights implementation, the rule of law and good governance. Thus, as the offered examples show, good governance is about ensuring human rights, as well as determining balance of human rights restriction in the public interest.

\section{IMPLEMENTATION OF THE RULE OF LAW}

Today, the rule of law is part of the values of the Western law tradition. The rule of law is defined in the constitutions of a number of states as a principle of public authority activity. For example, Art. 8 of the Constitution of Ukraine /67/ states that the principle of the rule of law is determined and operates in Ukraine. However, the state of its implementation depends on a number of factors, including the activities of lawyers, who "should take responsibility for the state of human rights protection and for the development of a democratic, law-based state in Ukraine" /68/.

In the Report on the Rule of Law Adopted by the Venice Commission /69/, the components of the rule of law include the following elements:

- legality, which also includes openness, under control and democratic nature of law-making;

- legal certainty;

- prohibition of arbitrariness;

- access to justice;

- respect for human rights;

- equality and non-discrimination.

In its judgments, the European Court of Human

Rights has repeatedly pointed to the necessity to respect the rule of law, which is directly stated in the preamble to the Convention for the Protection of Human Rights and Fundamental Freedoms /70/. In the case of Volokhy v. Ukraine /71/ the European Court of Human Rights noted in this context that national law should provide remedies

Galitsyna /62/, O. Dniprov /63/, O. Ihnatiuk and V. Horachuk /64/. 
against arbitrary interference by public authorities with human rights, especially when the powers of those bodies are exercised in secret. In this context, the conclusion of A. Kuchuk /72/ that the implementation of the principle of the rule of law involves the recognition of a person, his life and health as the basic value rather than the prevention or detection of criminal activity, (which, moreover, has to be carried out only by moral means and to provide for the professionalism of the bodies that counteract crime, and not to consider them amateurs, allowing the use of any means only if the purpose of the existence of such bodies was achieved).

In view of the abovementioned, it should also be noted that even in the context of countering a pandemic, public authorities are not endowed with unlimited powers and applying counterecting measures should respect human rights, human rights restrictions could not be disproportional. For example, in Ukraine, in order to prevent the spread of COVID-19, the movement of public transport was prohibited, all the planned measures were abolished, and the use of parks was banned $/ 73 /$, which caused a number of negative reactions from human rights organizations.

The rule of law, as it is known, is associated with England. The doctrinal phenomenon in the Federal Republic of Germany is the "Rechtsstaat", which is the basis of German constitutionalism, which is associated with the peculiarities of historical development and traditions $/ 74 /, / 75 /$.

The doctrine of the German "Rechtsstaat", as well as the English concept "the Rule of Law", was born in the general direction of formation and development of a new legal worldview, critique of feudal arbitrariness, affirmation of humanism ideas, principles of freedom and equality of all people, inalienable human rights, search ofvarious legal means and forms directed against the usurpation of public political power /76/.

A fairly systematic coverage of differences in the "the Rule of Law" understanding in English,
German and French legal doctrines was made by M. Loughlin /77/. As the author notes, the meaning of this term differs significantly, depending on the various management modes. Although a holistic formulation of the general concept of the rule of law can be developed, it is completely inoperable in practice. However, one cannot but agree with other authors who point out that by virtue of the universality of the rule of law concept, mutual understanding of that that human dignity and the restriction of public power through arbitrariness prohibition are the most important characteristics of the rule of law is achieved /78/ and that the doctrine the rule of law plays a crucial role in protecting human rights and fundamental freedoms $/ 79 /$. It should be mentioned that $\mathrm{S}$. Kirste /80/ argued that the rule of law and a law-abiding state can be understood as two formulations of a common goal, which differ in some results and institutional attitudes, but are combined by value criterion, and limit power. Accordingly, a lawabiding state and the rule of law can be inextricably linked to democracy.

Let us note that the rule of law, as mentioned by M.N.S. Sellers /81/ presupposes constitutionalism, which, in its turn, determines the necessity for the constitutional power existence (the constitution provides control over power). Accordingly, the rule of law requires, above all, an independent judiciary with the power to interpret and apply laws impartially. The goal of every society and every legal system should be justice for all people, free from oppression and arbitrary authorities. These words in general define the fundamental provisions inherent in the rule of law doctrine.

The rule of law was interpreted through the prism of legal positivism as the rule of the law or the legal law for a long time in Ukraine. "The current state of normative consolidation of the rule of law principle in the current legislation of Ukraine is characterized by insufficient specification of its content, ie in some acts of legislation it is mostly about the rule of the law, and not about the rule of law; the rule of law is viewed from the 
standpoint of public authorities, and not the public" /82/.

S. Holovaty /83/ rather systematically analyzed the rule of law (from the idea of the rule of law to the doctrine of the rule of law), comparing its understanding within the European legal systems and in Ukraine.

M. G. Haustova /84/ rightly notes that the principle of the rule of law is one of the leading elements of the constitutional order general principles of any modern democratic, law-based state. It is a derivative of all the general principles of law; as a value fusion of the justice ideas, equality, freedom and humanism, the rule of law forms the appropriate image of the legal system and determines the conditions that make it possible to turn this image into reality.

At the same time, it should be noted that under the influence of the Western tradition of law and the European Court of Human Rights activitiy, the legal doctrine of Ukraine is gradually rethinking the essence of law, its delimitation with the law, which contributes to a clearer understanding of the rule of law. Today, the rule of law, along with the principle of legality, is enshrined in a significant number of laws governing the public authorities' activities. At the same time there is a comprehension of such concepts as "proper governance", and "legal certainty". However, it should be agreed with S. Holovaty $/ 85 /$ that on the way to gaining real effectiveness with the principle of the Ukrainian constitutional order, which is enshrined in the law (the rule of law), there is a number of obstacles: (a) current Ukrainian legislation; (b) modern Ukrainian official legal doctrine; (c) the quality of the Ukrainian translation of the European Court of Human Rights judgments; (d) modern Ukrainian scientific legal doctrine. Thus, the rule of law is a complex and multifaceted phenomenon that includes a significant number of requirements for public authorities.

\section{V.} RECOMMENDATIONS

Within the Western law culture, as well as at the level of international universal organizations, the rule of law, human rights are recognized as fundamental values. In order to embody these values into social life, good governance should function. Good governance can only operate within the rule of law framework. Good governance, while ensuring human rights, should also take into account the public interests. In determining the balance between the public interest and human rights, good governance is governed by the rule of law, limiting human rights only proportionately, without placing undue burden on the individual and without violating the basic content of law.

This corresponds to the interests of a person, his aspirations, and therefore, the fall in the ratings of democracy and the rule of law can not indicate the devaluation of these phenomena, reducing their role in society. These ratings can only indicate certain changes in the activities of public authorities, which will be assessed by citizens in the time of the elections. A comparative analysis of the relationship between good governance, the rule of law and the public interest in the legal systems of the Federal Republic of Germany and Ukraine (states belonging to the continental law system that are members of the Council of Europe and subject to the Eropean Court of Human Rights jurisdiction) shows differences in perception of these phenomena, which is largely stipulated by the long prevalence of legal positivism in Ukraine and the lack of established democratic traditions. Even today in Ukraine the phenomena described by us are perceived through the principle of legality, which is interpreted purely from the standpoint of legal positivism.

The rule of law as well as democracy and human rights, are fundamental values of modern society. That is why public authorities should pay attention to the indicators of democracy and the rule of law, which show their decline, and take this into account in their activities. The Rule of Law Index 
and the Democracy Index should serve as benchmarks for assessing the fulfillment of human rights commitments by public authorities. The results obtained can be the basis for further epistemology of the relationship between the rule of law and the public interest and good governance.

Notes

/1/ Council of Europe. (1950), Convention for the Protection of Human Rights and Fundamental Freedoms. Retrieved from https://rm.coe.int/1680063765

/2/ Foreign and Commonwealth Office (2005), The role of human rights, democracy, and good governance in promoting sustainable development. London: Foreign and Commonwealth Office.

/3/ Pradeep, K. (2018), Human rights protection and good governance. New Delhi: Regal Publication.

14/ Aparov, A., Ivanii, O., Shestopalov, R., Adashys, L., \& Morozov, O. (2020), Right to education as a factor of education public administration in the European Court of Human Rights Practice. Revista Gênero \& Direito, 9(5), 238-254.

/5/ Mutagirov, D.Z. (2019), Paradigms of politics and political science. Political Expertise, 15(2), 201218.

/6/ Zhang, W. (2016), The relationship between rule of law, human rights, good governance and democracy. In Human Rights and Good Governance (pp. 1-13). Nijhoaff: Brill.

/7/ Sharma, B.M., \& Sharma, A. (2014), Development, good governance and human rights. Indian Journal of Public Administration, 60, 209-234.

/8/ Lamba, P. (2015), Good governance-a tool for the protection of human rights. Reserch Expo International Multidisciplinary Reserch Journal, V(IV), 32-37.

19/ Sangroula, Yu. (2014), Revisiting Concept of Human Rights, Rule of Law and Good Governance: A Discourse from Interface of Justice and Development from Experiences of People's Republic of China and South Asia. Retrieved from http://www.chinahumanrights.org/html/2014/PAPERS_1104/1132.html

/10/ World Justice Project. (2020), Rule of Law Index 2020. Retrieved from https://worldjusticeproject.org/our-work/research-and-data/wjp-rulelaw-index-2020

/11/ Lachmayer, K. (2020), Austria: rule of law lacking in times of crisis. Retrieved from https://verfassungsblog.de/rule-of-law-lackingin-times-of-crisis/

/12/ The Verkhovna Rada of Ukraine. (1996), Constitution of Ukraine No. 254k / 96-VR. Retrieved from https://zakon.rada.gov.ua/laws/show/254\%D0\%BA/96$\% \mathrm{D} 0 \% \mathrm{~B} 2 \% \mathrm{D} 1 \% 80$

/13/ Constitutional Court of the Federal Republic of Germany. (2006), Solution 1 BvR 357/05. Retrieved from https://www.bundesverfassungsgericht.de/Sha redDocs/Entscheidungen/DE/2006/02/rs200602 15_1bvr035705.html

/14/ Constitutional Court of the Federal Republic of Germany. (2021), Decision 1 BvR 2656/18, 1 BvR 78/20, 1 BvR 96/20, 1 BvR 288/20 (Klimaschutz). Retrieved from https://www.bundesverfassungsgericht.de/Sha redDocs/Entscheidungen/DE/2021/03/rs202103 24_1bvr265618.html

/15/ World Values Survey. (2020), World Values Survey 2020 in Ukraine. Retrieved from http://ucep.org.ua/doslidzhennya/worldvalues-survey-2020-in-ukraine.html

/16/ van Ham, C., \& Chappell, L. (2017), Democracy and human rights: a tripartite conceptual framework. Australian Journal of Human Rights, 23(2), 143-167.

/17/ Landman, T. (2018), Democracy and human rights: concepts, measures, and relationships. Politics and Governance, 6(1), 48-59.

/18/ Horn, A. (2020), The human right to democracy. Berlin/Boston: De Gruyter GmbH.

/19/ Economist Intelligence Unit. (2020), Democracy Index 2019. Retrieved from: https://www.eiu.com/topic/democracy-index

/20/ European Court of Human Rights. (2021), Pending Applications Allocated to a Judicial Formation Requêtes Pendantes Devant Une Formation Judiciaire. $\quad$ Retrieved from https://www.echr.coe.int/Documents/Stats_pending_month_2020_BIL.PDF

/21/ King, S.M., Chilton, B.S., \& Roberts, G. E. (2009), Reflections on defining the public interest. $A d-$ ministration \& Society, 41(8), 954-978.

/22/ Ho, L.-S. (2011), Public policy and the public interest (1st ed.). UK: Routledge.

/23/ Rekosh, E. (2005), Who defines the public interest? Public interest law strategies in central and eastern Europe. Sur. Revista Internacional de Direitos Humanos, 2(2), 166-179. 
/24/ Werpmann, R. (1999), The public interest: its meaning as a constituent element and as a dogmatic concept. Tübingen: Mohr Siebeck.

/25/ Viotto, R. (2009), The Public Interest. Transformations of a Controversial Legal Term. Baden-Baden: Nomos Universitätsschriften - Recht.

/26/ Parliamentary Council. (1949), Basic Law for the Federal Republic of Germany. Retrieved from https://www.gesetze-iminternet.de/gg/BJNR000010949.html

/27/ op. sit. in /25/

/28/ Schuster, B., Tizek, L., Schielein, M.C., Ziehfreund, S., Rothe, K., Spinner, C.D., Biedermann, T., \& Zink, A. (2021), Retracing the COVID-19 Pandemic in Germany from a Public Perspective using Google Search Queries Related to "coronavirus". Gesundheitswesen, 83 (5), e9-e14.

/29/ Gori, P., \& Pahladsingh, A. (2021), Fundamental rights under Covid-19: an European perspective on videoconferencing in court. ERA Forum, 21, 561-577.

/30/ Jovičić, S. (2021), COVID-19 restrictions on human rights in the light of the case-law of the European Court of Human Rights. ERA Forum, 21, 545-560.

/31/ Kolfschooten, v. H., Ruijter, de A. (2020), COVID19 and privacy in the European Union: A legal perspective on contact tracing. Contemporary Security Policy, 41(3), 478-491.

/32/ Galunko, V.V. (2010), Public interest in administrative law. Law Forum, 4, 178-182.

/33/ Dmitrenko, E. (2016), Features of correlation of public and private interest in financial law. Scientific Journal of the National Academy of the Prosecutor's Office of Ukraine, 2, 89-95.

/34/ Mykolenko, O. I. (2016), Public and private interests in administrative law. Law-Based State, 24, 100-104.

/35/ Karmalita, M. (2020), The principles of tax law as a manifestation of the balance of private and public interest. Law and Public Administration, 1(1), 56-62.

/36/ Chub, A. V. (2020), Legal public rights of an individual as a subject of administrative law. Prykarpattya Legal Bulletin, 3(32), 70-73.

/37/ Andrushko, I. P. (2011), The category of "public interest" in constitutional law: concept and content. Journal of Kyiv University of Law, 4, 137141.

/38/ Berestova, I. E. (2018), Public interests protection theoretical principles in civil proceedings and constitutional proceedings. Kyiv: FPE Masdakov.
/39/ Zolotukhina, L. O. (2019), The phenomenon of public interest as a category of administrative law. Kherson: "Helvetica" Publishing House.

/40/ op. sit. in /12/

/41/ Supreme Court. (2019), Resolution in the Case No. 810/2763/17 (K/9901/44258/18). Retrieved from https://reyestr.court.gov.ua/Review/79883398

/42/ op. sit. in /25/

/43/ Shevchuk, B. (2012), European principles of good governance and reform of the executive bodies system in Ukraine. Retrieved from http://www.lvivacademy.com/vidavnitstvo_1/visnik9/fail/Shevchuk_B.pdf

/44/ European Court of Human Rights. (2009), Case of Moskal v. Poland (Application no. 10373/05). Retrieved from http://hudoc.echr.coe.int/app/conversion/pdf/?library $=E C H R \& i d=001-94009 \&$ filename $=001-$ 94009.pdf

/45/ op. sit. in /1/

/46/ op. sit. in /44/

/47/ European Court of Human Rights. (2014), Case of Paplauskienè v. Lithuania (Application no. 31102/06). Retrieved from http://hudoc.echr.coe.int/eng?i=001-147012

/48/ European Court of Human Rights. (2013), Case of Pyrantienė v. Lithuania (Application no. 45092/07). Retrieved from http://hudoc.echr.coe.int/eng?i=001-128040

/49/ European Court of Human Rights. (2014), Case of Albergas and Arlauskas v. Lithuania (Application no. 17978/05). Retrieved from http://hudoc.echr.coe.int/eng?i=001-144619

/50/ European Court of Human Rights. (2011), Case of Rysovskyy v. Ukraine (Application no. 29979/04). Retrieved from http://hudoc.echr.coe.int/eng?i=001-107088

/51/ Offe, C. (2015), “Good Governance”. In: Krell, C., Mörschel, T. (Eds.). Values and politics. Wiesbaden: Springer VS.

/52/ Ministry of Economic Cooperation and Development of the Federal Republic of Germany. (2021), Promote good governance drive development. Retrieved from https:/www.bmz.de/de/entwicklungspolitik/g ute-regierungsfuehrung

/53/ Niebel, D. (2012), Vorvort. In: Good governance in practice. Approaches and examples from development policy Praxis: BMZ-Informationsbroschüre.

/54/ Vogel, B., Dolzer, R., \& Herdegen, M. (Eds.). (2007), Good governance. Good governance in the 21st century. Verlag: Herder. 
/55/ Kessler, C. (2009), Requirements and limits of good governance - claims of the north, perspectives of the south in: Seifert, M., Wehr, I., Weiland, H.(ed.) Good governance at a dead end? (pp. 125242). Wiesbaden: Springer VS.

/56/ Czada, R. (2013), Good governance as a guiding concept for government action: basics, applications, criticism. In A. Benz \& N. Dose (Eds.), Governance $\tilde{n}$ governing in complexregulatory systems. An introduction (pp. 201-224). Wiesbaden: Springer VS.

/57/ Werther-Pietsch, U. (2020), Collective security 2030. Global peacekeeping in transition. Wien: ReproZ W.

/58/ Federal Ministry of Labour and Social Affairs. (2020), Respect for human rights along global value chains. Risks and opportunities for sectors of the German economy. Retrieved from https://www.nachhaltige-agrarlieferketten.org/fileadmin/media/fb-543-achtung-vonmenschenrechten-entlang-globalerwertschoepfungsketten.pdf

/59/ Lendel, M.O. (2014), The perspectives of the good governance principles in Ukraine in the context of european integration. Grani, 7(111), 96-111.

/60/ Kukhareva, G. P. (2015), Good governance as a way to establish an effective system of public administration in Ukraine. Theory and Practice of Public Administration, 3 (50), 76-83.

/61/ Arifkhodzhjaeva, T.B. (2016), The concept of public administration in the field of population social protection. Law Forum, 3, 2-15.

/62/ Galitsyna, N.V. (2020), Principles of "good governance" and "good administration" in administrative law. Legal Bulletin, 13, 101-110.

/63/ Dniprov, O. (2021), Principles of good governance in the modern system of administrative law of Ukraine. Entrepreneurship, Economy and Law, 1, 114-118.

/64/ Ihnatiuk, O., \& Horachuk, V. (2021), Basic principles of public administration in the legal field of Ukrainian legislation. Investments: Practice and Experience, 8, 98-104.

/65/ Ezerov, A., \& Batan, Y. (2016), Proper introduction and provision of administrative services of local governments municipality. Legal Bulletin, 2, 109116.

/66/ op. sit. in /59/

/67/ op. sit. in /12/

/68/ Saienko, M.I., Dobroboh, L.M., Pozigun, I.O., \& Orlova, O.O. (2020), Legal clinical education: Ukrainian experience educación clínica legal: experiencia ucraniana. Educational Psychology
Practices in Europe and the Middle East, 8, SPE(2), 686.

http://dx.doi.org/10.20511/pyr2020.v8nSPE2.68 6

/69/ The Venice Commission. (2011), Report on the Rule of Law Adopted by the Venice Commission at its 86th plenary session (Venice, 25-26 March 2011). Retrieved from http://www.venice.coe.int/docs/2011/CDLAD\%282011\%29003rev-e.pdf.

/70/ op. sit. in /1/

/71/ European Court of Human Rights. (2006), Case of Volokhy v. Ukraine (Application no. 23543/02), Retrieved from http:/hudoc.echr.coe.int/eng?i=001-77837

/72/ Kuchuk, A.M. (2017), Theoretical foundations of law polycentrism. Dnipro: Dnipro State University of Internal Affairs affairs; Lira LTD.

/73/ Cabinet of Ministers of Ukraine. (2020), On Prevention of the Spread of Acute Respiratory Disease COVID-19 Caused by Coronavirus SARS-CoV2 on the Territory of Ukraine. No. 211. Retrieved from https://zakon.rada.gov.ua/laws/show/2112020-\%D0\%BF\#Text

/74/ Pfordten, D. (2014), On the foundations of the rule of law and the principle of the legal state/rechtsstaat. In: Silkenat J., Hickey Jr. J., Barenboim P. (Eds.) The Legal Doctrines of the Rule of Law and the Legal State (Rechtsstaat). Ius Gentium: Comparative Perspectives on Law and Justice, vol. 38. Cham: Springer. https://doi.org/10.1007/978-3-319-05585-5_2

175/ From Krygier, M. (2015), Rule of Law (and Rechtsstaat). In: J.D. Wright (Ed.). International Encyclopedia of the Social $\mathcal{E}$ Behavioral Sciences, 2nd edition, Vol 20 (pp. 780-787). Oxford: Elsevier.

/76/ Vaughn, D D. (Ed.), (2016), The rule of law and human rights in the light of the Convention for the Protection of Human Rights and Fundamental Freedoms. Kyiv: USAID.

/77/ Loughlin, M. (2010), Rechtsstaat, Rule of Law, l'Etat de droit. In: Loughlin, M. Foundations of Public Law (pp. 312-341). Cham: Springer.

/78/ Venter, F. (2014), The rule of law as a global norm for constitutionalism. In: Silkenat J., Hickey Jr. J., Barenboim P. (Eds.) The Legal Doctrines of the Rule of Law and the Legal State (Rechtsstaat). Ius Gentium: Comparative Perspectives on Law and Justice, vol. 38 (pp. 91-104). Cham: Springer.

/79/ Dedov, D. (2014), The rule of law and legal state doctrines as a methodology of the philosophy of law. In: Silkenat J., Hickey Jr. J., Barenboim P. 
(Eds.) The Legal Doctrines of the Rule of Law and the Legal State (Rechtsstaat). Ius Gentium: Comparative Perspectives on Law and Justice, vol. 38 (pp. 61-69). Cham: Springer.

/80/ Kirste, S. (2014), Philosophical foundations of the principle of the legal state (rechtsstaat) and the rule of law. In: Silkenat J., Hickey Jr. J., Barenboim P. (Eds) The Legal Doctrines of the Rule of Law and the Legal State (Rechtsstaat). Ius Gentium: Comparative Perspectives on Law and Justice, vol 38 . Springer, Cham. https://doi.org/10.1007/978-3-319-05585-5_3

/81/ Sellers, M.N.S. (2014), What is the rule of law and why is it so important? In: Silkenat J., Hickey Jr. J., Barenboim P. (Eds.) The Legal Doctrines of the
Rule of Law and the Legal State (Rechtsstaat). Ius Gentium: Comparative Perspectives on Law and Justice, vol 38 (pp. 3-13). Cham: Springer.

/82/ Padalka, R. O. (2017), The rule of law as a fundamental principle of law. Kyiv: National Pedagogical University named after M. P. Dragomanov.

/83/ Holovaty, S. P. (2006), Rule of law. Kyiv: "Phoenix" Publishing House.

184/ Haustova, M.G. (2018), The rule of law - as a fundamental principle of the legal system of Ukraine in terms of modernization. In: Human Rights and Democracy (pp. 40-45). Kharkiv: Yaroslav the Wise National University of Law.

185/ Holovaty, S. (2019), "The rule of law" does not work. Law of Ukraine, 11, 39-82. 